\title{
PENGARUH PENGGUNAAN MEJA KURSI ERGONOMI TERHADAP KEMAMPUAN KOORDINASI MOTORIK ANAK KELAS 3 SD ALAM AQILA WONOSARI KLATEN
}

\author{
Haris Sutopo, Iffah Nurhayati \\ Poltekkes Kemenkes Surakarata Jurusan Okupasi Terapi
}

\begin{abstract}
Background: The effect of the use of ergonomic chair table, Motoric coordination, 3rd grade Elementary School.The purpose of the study was to determine the effect of the use of ergonomic chair tables on motoric coordination ability of grade 3 students at SD Alam Aqila Wonosari Klaten. Method: Data analysis was carried out through quantitative analysis with paired sample t-test and data compatibility test in both groups before treatment using parametric test (independent sample t-test), from the results of examination using VMI Beery, mean before use ergonomic chair table at 19.13 and after the use of ergonomic chair desk for 23.31. Result: The effect of using ergonomic chair table can be seen by comparing the data before and after using the ergonomics chair table using paired sample t-test. the value obtained with a 95\% confidence level is -6,330 to -2,045. Conclusion: Use of Ergonomic Chair Tables can improve motoric coordination ability of grade 3 SD Alam Aqila Wonosari Klaten.
\end{abstract}

Keywords: Ergonomics, Ergonomic Chair Table, Motor Coordination.

\section{PENDAHULUAN}

Koordinasi motorik adalah fungsi harmonis bagian tubuh yang melibatkan gerakan motorik kasar, motorik halus dan perencanaan gerakan (motor planning). Gangguan koordinasi motorik dapat menyebabkan Developmental Coordination Disorder (DCD), yang dikenal juga dengan nama clumsiness dan dyspraxia. Clumsiness adalah salah satu gangguan perkembangan yang ditandai dengan gangguan bermakna koordinasi motorik (Made Supartha, dkk., 2009). Sedangkan gangguan perkembangan motorik pada keadaan dyspraxia dapat menyebabkan berbagai gangguan aktivitas sehari-hari, yang tidak hanya memengaruhi gangguan koordinasi motoriknya saja, namun juga akan menimbulkan masalah dalam performa akademis, perilaku, dan emosi anak dibandingkan teman sebaya. Literatur menyebutkan clumsiness atau dyspraxia diperkirakan terjadi pada sekitar 6\%-13\% anak (Made Supartha, dkk., 2009). Literatur lain menyebutkan bahwa 1 dari 30 anak menderita dyspraxia (Gaines, et al., 2008).

Selain kemampuan siswa, faktor yang dapat mempengaruhi kemampuan menulis adalah postur dan posisi duduk, menggunakan peralatan kelas yang ergonomis penting dan dapat memperbaiki proses pendidikan dan pelatihan. (Zunjic, 2013). Menurut Hira (1980) penggunaan meja dan kursi yang tidak ergonomis (postur yang tidak baik) ketika belajar, dapat menyebabkan terganggunya kegiatan belajar dan berpengaruh terhadap ketertarikan siswa dalam proses belajar.

Dampak dari ketidak sesuaian antara meja kursi dengan ukuran tubuh 
anak sekolah merupakan salah satu kendala dalam upaya meningkatkan sumber daya manusia yang berkualitas. Akibat dari meja kursi sekolah yang tidak sesuai dengan ukuran tubuh anak sekolah dapat mengakibatkan anak cepat mengalami kelelahan perasaan tidak nyaman (gelisah), kurang konsentrasi dan mengantuk, apabila kondisi tersebut berlangsung lama (selama masa sekolah), akibat lebih jauh akan menyebabkan perubahan sikap tubuh dan gangguan pertumbuhan ( Suhardiono, 2005).

\section{METODE PENELITIAN}

Penelitian ini merupakan penelitian pre-experimental design dengan metodepre and post with one group design. Penelitian ini bertujuan untuk mengetahui pengaruh penggunaan meja ergonomi terhadap handwriting skillsanakkelas 3 SD Alam Aqila Wonosari Klaten.

Siswa kelas 3 diberikan perlakuan menggunakan meja kursi ergonomi untuk mengerjakan beberapa pemeriksaan terstandar bertujuan membandingkan antara hasil awal atau sebelum intervensi (pre-test) dan hasil akhir setelah adanya intervensi (post-test), mengetahui perbedaan hasil intervensi dan membuktikan bahwa penggunaan meja ergonomi berpengaruh terhadap koordinasi motorik anak kelas 3 SD Alam Aqila Wonosari Klaten.

\section{HASIL PENELITIAN}

Berdasarkan jenis kelamin, dari total 16 responden yang diteliti sebagian besar berjenis kelamin laki-laki sebanyak 13 orang $(81,3 \%)$, sedangkan perempuan 3 orang $(18,8 \%)$. Berdasarkan Umur responden yang diteliti didominasi responden berumur 8 tahun sebanyak 8 orang (50\%), sedangkan yang beumur 9 tahun sebanyak 4 orang $(25 \%)$ dan 7 tahun sebanyak 4 orang (25\%). Distribusi nilai Koordinasi Motorik yang didapatkan pada pemeriksaan pretest dan posttest dapat dilihat pada tabel 1 .

Tabel 1. Rerata Nilai Pretest dan Posttest VMI

\begin{tabular}{ccc}
\hline VMI & Pretest & Posttest \\
\hline Rerata & 19.12 & 23.31 \\
\hline
\end{tabular}

Dari tabel diatas diketahui bahwa Nilai Pretest adalah 19.12 dan nilai posttest adalah 23.31 sehingga diperoleh selisih nilai sebesar 4.19.

Berdasarkan uji paired sample ttest sebelum dan sesudah penggunaan meja kursi ergonomi, maka diperoleh $\rho$ value $p=0,001<0,05$ yang berarti ada perbedaan bermakna pada nilai sebelum dan sesudah penggunaan meja kursi ergonomic dapat dilihat di tabel 2.

Tabel 2. Hasil Analisis Paired Sample TTest

\begin{tabular}{l}
\hline \multicolumn{1}{c}{ Variabel } \\
\hline $\begin{array}{c}\text { Total nilai VMI Pretest } \\
\text { dan Posttest }\end{array}$ \\
\hline \multicolumn{1}{c}{ Sehingga dapat disimpulkan } \\
bahwa penggunaan meja kursi ergonomi \\
$\begin{array}{l}\text { mempunyai pengaruh terhadap koordinasi } \\
\text { motorik anak kelas } 3 \text { SD Alam Aqila }\end{array}$ \\
Wonosari Klaten.
\end{tabular}

\section{PEMBAHASAN}

Penelitian dilakukan di SD Alam Aqila Wonosari Klaten dengan responden penelitian diambil anak kelas dua yang memiliki kriteria sesuai yang diharapkan peneliti dengan instrument pemeriksaan yang digunakan. 
Pengukuran dengan menggunakan Beery Visual Motor Integration (VMI) pada area Motor Coordination pada form pemeriksaan Motor Coordination.

Hasil uji statistik yang dilakukan kepada enam belas anak sebagai responden dari penelitian ini anak berusia delapan sampai dengan sepuluh tahun sesuai usia normal kelas 3 SD dengan rasio perbandingan usia delapan tahun empat orang atau $25 \%$, usia Sembilan tahun delapan orang atau $50 \%$ dan usia sepuluh tahun empat orang atau $25 \%$.

Menurut jenis kelamin laki-laki tiga belas orang atau $81,3 \%$ dan perempuan berjumlah tiga orang atau 18,8\% karena memang di SD Alam Aqila sebagian besar siswa adalah perempuan.

Berdasarkan uji statistik yang dilakukan terhadap nilai pre test dan post test penggunaan meja kursi ergonomi dengan menggunakan paired sample t-test diperoleh hasil significancy $\rho$-value $0,001<0,05$ yang berarti terdapat perbedaan rerata nilai sebelum dan sesudah penggunaan meja kursi ergonomi terhadap koordinasi motoric dan nilai yang didapatkan dengan tingkat kepercayaan $95 \%$ adalah sebesar -6.330 s/d -2.045.

Penggunaan meja kursi ergonomi yang dirancang sesuai dengan postur anak memberikan pengaruh terhadap koordinasi motorik, meja kursi ergonomi memberikan dukungan terhadap hasil menulis anak, keterbacaan bentuk gambar dan kestabilan pola memegang pensil serta meningkatkan daya tahan duduk dan kenyamanan selama proses pembelajaran di kelas.

Hal ini sesuai dengan penelitian yang dilakukan oleh Zunjic (2015) tentang Peran Ergonomi untuk peningkatan pendidikan memberikan menjelasan bahwa pengukuran antropometri sangat penting dan merupakan aspek yang harus diperhitungkan dalam mendesain furniture di kelas dengan pengukuran khusus seperti tinggi popliteal, tinggi lutut dan tinggi siku penting untuk menentukan dimensi furnitur sekolah yang tepat sesuai dengan postur siswa, Penggunaan furnitur yang yang sesuai pada anak lebih penting dari pada orang dewasa, posisi duduk yang tidak bagus sejak masa anak- anak dan berlangsung pada waktu lama akan sulit dirubah setelah dewasa, sikap duduk yang tepat merupakan elemen penting dalam pencegahan gejala gangguan musculoskeletal.

\section{KESIMPULAN DAN SARAN}

Penelitian pengaruh penggunaan meja kursi ergonomi terhadap Koordinasi Motorik yang dilakukan di SD Alam Aqila Wonosari Klaten menggunakan jenis penelitian kuantitatif preexperimental design dengan metode pre and post with one group design menggunakan instrument Beery Visual Motor Integration (VMI). proses pengolahan data menggunakan statistik parametris dengan uji hipotesis komparatif dengan teknik analisis data paired sample t-test. Sample penelitian adalah siswa kelas 3 dengan jumlah enam belas anak yang terdiri dari tiga belas anak laki-laki dan tiga anak perempuan dengan rentang usia tujuh sampai sembilan tahun. Nilai yang diperoleh berdasarkan jenis kelamin laki-laki lebih besar dari perempuan dan umur sembilan tahun memperoleh nilai selisih paling tinggi dibandingkan umur tujuh dan delapan tahun.

Penulis merasa dalam penelitian ini banyak kekurangan dan diperlukan penelitian lebih lanjut yang serupa dengan 
desain meja kursi yang lebih bagus dan memperbanyak jumlah responden.

\section{DAFTAR RUJUKAN}

Beery., K.(1969). Developmental Test of Visual Motor Integration: Administration and scoring manual. california: Follet publishing company. Nasional III Penyakit kelenjar tiroid. BP Undip: Semarang.

Glinka, J., Artaria, M. D., \& Koesbardiati, T. (2008). Metode pengukuran manusia. Surabaya: Airlangga University Press

Kroemer, K., Kroemer, H., \& Kroemer, K. E. (2001). Ergonomics: How to design for ease and efficiency. New Jersey: Prentice Hall.

Musaed, Z. (2008). Effect of chair design on rating of discomfort. Occupational Therapy Department. Faculty of Allied Health Science. Kuwait University. Kuwait

Nurmianto, E. (2008). Ergonomi konsep dasar dan aplikasinya. Surabaya: Guna Widia.

Sugianto, R.(2014). Hubungan ukuran meja dan kursi ergonomis dengan kenyamanan melalui posisi duduk murid taman kanak-kanak Dewi Sartika Surabaya. Departemen Antropologi FISIP Unair. Surabaya.

Suhardiono. (2005). Dampak meja kursi sekolah yang tidak ergonomis terhadap kesehatan anak sekolah dasar. Jurnal Mutiara Kesehatan Indonesia.

Tarwaka, et al.(2004). Ergonomi untuk keselamatan, kesehatan kerja dan produktivitas. UNIBA, Surakarta.

Wayne, J., et al.(2013). Biomechanical and ergonomic assessment of urban transit operators. Occupational Performance Laboratory. University of New Brunswick. Canada.

Wen, Y., et al.(2012). An onsite ergonomics assesment for risk of work-related musculoskeletal disorder among cooks in a Chinese restaurant. Case Study. Department of Rehabilitation Science, The Hong Kong Polytechnicf University Hong Kong

Zunjic, A., et al.(2013). The role of ergonomics in the improvement of quality of education. Faculty of Mechanical Engineering. University of Belgrade, Serbia 